\title{
Do Tick Attachment Times Vary between Different Tick-Pathogen Systems?
}

\author{
Stephanie L. Richards ${ }^{1, *}$, Ricky Langley ${ }^{2}$, Charles S. Apperson ${ }^{3}$ and Elizabeth Watson ${ }^{4}$ \\ 1 Department of Health Education and Promotion, Environmental Health Science Program, \\ East Carolina University, Greenville, NC 27858, USA \\ 2 Toxicology Program, North Carolina State University, Raleigh, NC 27695, USA; rick.langley@dhhs.nc.gov \\ 3 Department of Entomology, North Carolina State University, Raleigh, NC 27695, USA; apperson@ncsu.edu \\ 4 Animal Hospital of Boone, Boone, NC 28607, USA; lizwatson489@gmail.com \\ * Correspondence: richardss@ecu.edu; Tel.: +252-328-2526
}

Academic Editor: Andrea Cattaneo

Received: 30 March 2017; Accepted: 4 May 2017; Published: 9 May 2017

\begin{abstract}
Improvements to risk assessments are needed to enhance our understanding of tick-borne disease epidemiology. We review tick vectors and duration of tick attachment required for pathogen transmission for the following pathogens/toxins and diseases: (1) Anaplasma phagocytophilum (anaplasmosis); (2) Babesia microti (babesiosis); (3) Borrelia burgdorferi (Lyme disease); (4) Southern tick-associated rash illness; (5) Borrelia hermsii (tick-borne relapsing fever); (6) Borrelia parkeri (tick-borne relapsing fever); (7) Borrelia turicatae (tick-borne relapsing fever); (8) Borrelia mayonii; (9) Borrelia miyamotoi; (10) Coxiella burnetii (Query fever); (11) Ehrlichia chaffeensis (ehrlichiosis); (12) Ehrlichia ewingii (ehrlichiosis); (13) Ehrlichia muris; (14) Francisella tularensis (tularemia); (15) Rickettsia 364D; (16) Rickettsia montanensis; (17) Rickettsia parkeri (American boutonneuse fever, American tick bite fever); (18) Rickettsia ricketsii (Rocky Mountain spotted fever); (19) Colorado tick fever virus (Colorado tick fever); (20) Heartland virus; (21) Powassan virus (Powassan disease); (22) tick paralysis neurotoxin; and (23) Galactose- $\alpha$-1,3-galactose (Mammalian Meat Allergy-alpha-gal syndrome). Published studies for 12 of the 23 pathogens/diseases showed tick attachment times. Reported tick attachment times varied ( $<1 \mathrm{~h}$ to seven days) between pathogen/toxin type and tick vector. Not all studies were designed to detect the duration of attachment required for transmission. Knowledge of this important aspect of vector competence is lacking and impairs risk assessment for some tick-borne pathogens.
\end{abstract}

Keywords: duration of tick attachment; tick-borne disease; tick; transmission dynamics

\section{Introduction}

Ticks (Class Arachnida; Order Acari) are widespread across the United States (US) and tens of thousands of tick-borne diseases are reported yearly in the US. Approximately 40 tick species blood feed on humans in the US [1] and at least 11 of these species are known to transmit infectious agents [2-4]. The Centers for Disease Control and Prevention recognizes the following tick-borne diseases and pathogens in the US: Anaplasmosis, babesiosis, Borrelia miyamotoi disease, Colorado tick fever, ehrlichiosis, Heartland virus, Lyme disease, Powassan disease, Rickettsia parkeri rickettsiosis, Rocky Mountain spotted fever, tick-borne relapsing fever, tick paralysis, tularemia, Q-fever, and 364D rickettsiosis [4].

Numerous studies have documented tick exposure as an occupational health issue for forestry personnel and others working (e.g., agricultural industry, military) and/or participating in recreational activities (e.g., hunting, hiking) where tick exposure is common. A study in Germany showed evidence for previous infection of foresters for tick borne pathogens Bartonella Strong, Borrelia burgdorferi Johnson, 
Coxiella burnetii Derrick, Francisella tularensis McCoy and Chapin, and tick-borne encephalitis virus [5]. The same study reported a high incidence (31\%) of Borrelia burgdorferi (the causative agent of Lyme disease) seropositivity in participants was related to these characteristics: (1) male; (2) $\geq 50$ years old; (3) reported $>50$ tick bites; and (4) worked in the forest. A study in Poland also found high incidence (50\%) of Borrelia burgdorferi antibodies in forestry workers [6]. A study in US National Park Service employees showed prior infections with tick-borne pathogens, such as Bartonella henselae Regnery, spotted fever group rickettsiae, and Anaplasma phagocytophilum Foggie [7]. However, most studies, including the aforementioned studies, do not ask participants about how long ticks were attached before being discovered/removed. In order to develop strategies to prevent occupational and recreational exposure to ticks and tick-borne diseases, we must have improved knowledge and education of risk factors [5]. This includes health education about the importance of removing ticks as quickly as possible to reduce the chance of pathogen exposure. A study in military personnel showed that health education increased self-awareness and removal of ticks and this reduced tick bites [8]. Military personnel may be exposed to tick-infested areas for multiple days (unlike foresters and/or recreational exposure), hence, removal of ticks while in the field is essential to reduce attachment times that can lead to pathogen transmission by infectious ticks. Individuals can also use preventative measures, such as wearing permethrin-treated clothing and/or repellant, in order to minimize tick exposure risk. Studies have shown these types of practices can reduce the incidence of tick bites, hence, reducing the potential for pathogen exposure $[9,10]$.

Pathogen transmission by ticks depends on a variety of factors including duration of feeding time, pathogen titer, and extent of tissue (e.g., gut, salivary glands) infection at the time of blood feeding. Some pathogens require a period of replication and/or expansion (in response to a blood meal) prior to transmission from a tick. Consequently, host infection may be prevented if the tick is removed within a critical period of time after attachment; i.e., the longer a tick remains attached, the higher the likelihood that an infectious pathogen dose is transmitted [11-13]. Replication and/or expansion has been documented for bacterial pathogens causing Rocky Mountain spotted fever, anaplasmosis, Lyme disease, and babesiosis [14]. Tick-borne viruses differ from bacteria in the duration of replication/expansion required (if any) and may be transmitted more rapidly than bacteria [12,14]. It is important to note that not all ticks can become infected with, and transmit, all pathogens. Non-competent ticks may be able to acquire a pathogen from a host during blood feeding, but may not be able to sustain the pathogen through molting, and/or be able to transmit the pathogen. Immune responses to pathogens may be greater in non-vector competent ticks compared to ticks that are competent vectors $[15,16]$.

Our findings indicate that the duration of tick attachment to vertebrates required for transmission of pathogens (e.g., bacteria, viruses) varies, with most information derived from experimental studies conducted on rodents e.g., [14,17]. The few studies of humans have largely been clinical investigations of disease case patients, e.g., [18,19]. Engorgement indices (the ratio between total tick body length and scutum length (or width); the ratio between alloscutum width and scutum width) were calculated to determine the duration of feeding for Ixodes scapularis Say [20]. It is unknown whether these indices can be applied equally to all tick species. After $24 \mathrm{~h}$ of attachment to laboratory rabbits, engorgement indices increased steadily in I. scapularis when assayed at 36,48 , and $60 \mathrm{~h}$ post-attachment [20]. The total tick body length and alloscutal width increased with increased blood feeding attachment time, while scutal length and width remained the same. The same study showed that, based on the engorgement indices, most (64\%) adult ticks submitted for pathogen testing (for a variety of pathogens, such as Borrelia burgdorferi) by human bite victims had been attached for $\leq 36 \mathrm{~h}$, while only $41 \%$ of nymphs were removed at the same time point.

Hard ticks (Arachnida: Acari: Ixodidae) can mate on (usually Metastriata) or off (usually Prostriata) the host [21]. After attachment, the mated female hard tick will engorge to ca. 100-200 times her unfed weight (depending on tick species) in order to develop eggs and subsequently oviposit [15,22]. A virgin female tick usually feeds only until the critical weight (10 times her unfed weight) is achieved and 
may wait on a host until a male finds her and copulation takes place [22]. If a virgin tick is removed prior to mating, she may continue blood feeding at a later time if she has not yet reached the critical weight [22]. Once attached to a vertebrate host, a mated female hard tick feeds for four to 15 days to acquire enough blood to develop eggs [22,23]. There is an initial slow feeding phase ( $\geq 7$ days in adults) where the hard tick increases in size by ca. 10 times (critical weight) (in virgin and mated females), followed by a rapid feeding phase (12-24 h) (in mated females only) [22,23]. Others have shown that the mating stimulus for the rapid feeding phase in females may be something the male inserts via spermatophore, but not necessarily sperm, as irradiated male sperm (sterile) have still been shown to stimulate rapid feeding in Dermacentor variabilis Say [24]. The virgin female tick does not feed to a level above the critical weight so she can (1) remain small and reduce the chances of being detected (and potentially removed by grooming) by the host, or (2) have the opportunity to reattach to another host to find a mate, if needed [22].

Hard ticks secrete an adhesive "cement" composed of proteins during the first five to 30 min of attachment (during the slow feeding phase) that helps secure them to the host $[23,25,26]$. Over time, additional layers of cement are secreted [27]. Studies on tick-borne encephalitis virus have shown higher virus titers in the cement plug than in the tick body (e.g., Ixodes ricinus (L.), Ixodes persulcatus Schulze), hence, even after a tick is removed, disease-causing pathogens may still be present in the host [26]. Mouthparts of different tick genera differ in length (e.g., shorter mouthparts extending into the dermis and epidermis for Dermacentor, Haemophysalis, and Rhipicephalus, compared to longer mouthparts extending more deeply into the dermis for Amblyomma and Ixodes) [15]. The amount of pathogens in the mouthparts of the tick would be expected to vary between vector-pathogen systems, hence, leaving remnants of tick mouthparts in the body after removal may leave pathogens behind, and possibly result in secondary infection [28]. However, if the tick and tissue surrounding the tick bite site are removed before pathogens (e.g., spirochetes) have had time to disperse, infection may be prevented [29].

Soft ticks (Arachnida: Acari: Argasidae) mate off the host, tend to inhabit animal burrows, and require a shorter feeding time (ca. 30-60 min) to fully engorge than hard ticks [15]. The weight of a blood-fed female soft tick is ca. five to 12 times her unfed weight [30] and, unlike hard ticks, mating status does not influence the blood meal size [22]. Based on documented differences in engorgement periods, pathogen transmission by soft ticks may occur more rapidly than via hard ticks. Others have shown a dose-dependent relationship for successful pathogen transmission demonstrated by simultaneous blood feeding by multiple soft ticks (e.g., three Ornithodoros turicata Duges start transmitting Borrelia turicatae to mice within 15-40 s (tick-borne relapsing fever)) [31].

Here, we review some important pathogens of public health concern transmitted by hard and soft ticks and associated diseases with a focus on the US. For each disease, we investigated the known tick vectors and (if known), and the duration of tick attachment required for pathogen transmission.

\section{Materials and Methods}

We used worldwide literature retrieval databases: PubMed, Web of Science, Armed Forces Pest Management Board Literature Retrieval System, and Google Scholar. Terms used in the literature search included: "duration of tick attachment and tick-borne diseases", "transmission dynamics of tick-borne diseases", "anaplasmosis", "ehrlichiosis", "Rocky Mountain spotted fever", "Rickettsia parkeri", "tularemia", "Colorado tick fever", "Powassan disease", "babesiosis", "Lyme disease", "Southern tick-associated rash illness", "tick-borne relapsing fever", "Borrelia miyamotoi", "Heartland virus", "364D rickettsiosis", "tick paralysis", "occupational health tick exposure", and "tick meat allergy". Literature searches were conducted between January 2014 and April 2017. Reference sections of primary articles were also reviewed for related publications.

\section{Results}

A summary of associated tick vectors and the duration of tick attachment time for transmission (if known) are listed in Table 1. 
Table 1. Summary of attachment times reported in publications. Primary known US vector(s) are indicated in bold.

\begin{tabular}{|c|c|c|c|c|}
\hline Pathogen(s) & Associated Disease & Arthropod Epidemiologic Vectors in US & $\begin{array}{l}\text { Estimated Duration of Attachment } \\
\text { Time to Transmit Pathogen }\end{array}$ & $\begin{array}{l}\text { References for Attachment Time } \\
\text { (Time Points Examined-Host) }\end{array}$ \\
\hline Anaplasma phagocytophilum & Anaplasmosis & I. scapularis *, I. pacificus & $24 \mathrm{~h}-50 \mathrm{~h}$ & $\begin{array}{l}{[32](24,48,72 \mathrm{~h}-\mathrm{C} 3 \mathrm{H} / \mathrm{HeJ} \text { and }} \\
\text { C3H/Smn.CIrHSD mice); } \\
{[33](12,24,30,36,50 \mathrm{~h}-\mathrm{C} 3 \mathrm{H} / \mathrm{HeJ} \text { mice })}\end{array}$ \\
\hline Babesia microti & Babesiosis & I. scapularis * & $\begin{array}{l}7-18 \text { days } \\
36-54 \mathrm{~h}\end{array}$ & $\begin{array}{l}\text { [34] (every } 24 \mathrm{~h} \text { from } 6-25 \text { days-voles); } \\
{[34](36,48,54 \text { h-hamsters) }}\end{array}$ \\
\hline Borrelia burgdorferi & Lyme disease & I. scapularis *, I. pacificus * & $\begin{array}{l}4-72 \mathrm{~h} \text { (Ixodes scapularis); } \\
48-96 \mathrm{~h} \text { (Ixodes pacificus) }\end{array}$ & $\begin{array}{l}{[17](24,48,72, \geq 96 \mathrm{~h} \text {-deer mice); }} \\
{[35](24,48,72 \mathrm{~h}, \geq 96 \mathrm{~h} \text {-mice); }} \\
{[36](24,48,60,72,96,192 \mathrm{~h} \text {-only salivary }} \\
\text { glands tested [no host transmission]; } \\
{[37](4,12 \mathrm{~h} \text {-human clinical case report) }}\end{array}$ \\
\hline Borrelia lonestari **, possibly other Borrelia spp. & Master's disease, Southern tick associated rash illness & A. americanum * & Unknown & $\mathrm{n} / \mathrm{a}$ \\
\hline Borrelia turicatae, Borrelia hermsii & Tick-borne relapsing fever & O. hermsii *, O. turicata *, O. parkeri & $\begin{array}{l}15 \mathrm{~s}-30 \mathrm{~min} \\
\text { (transmission related to [rapid] time for } \\
\text { engorgement in soft ticks) }\end{array}$ & $\begin{array}{l}\text { [38] (6-23 min-unknown host; } \\
\text { [31] (15 s, } 30 \text { min-Swiss Webster mice) }\end{array}$ \\
\hline Borrelia hermsii, Borrelia parkeri & Tick-borne relapsing fever & O. hermsii *, O. turicata *, O. parkeri & Unknown & $\mathrm{n} / \mathrm{a}$ \\
\hline Borrelia mayonii & Borreliosis **** & I. scapularis * & $24-96 \mathrm{~h}$ & [39] $(24,48,72,96$ h-CD-1 mice $)$ \\
\hline Borrelia miyamotoi & Borrelia miyamotoi disease (Borreliosis) **** & I. pacificus *, I. scapularis* & $24-96 \mathrm{~h}$ & {$[40](24,48,72,73-96 \mathrm{~h}$-mice $)$} \\
\hline Coxiella burnetii & Query Fever & $\begin{array}{l}\text { A. americanum, A. cajennense, D. andersoni }{ }^{*} \text {, } \\
\text { D. occidentalis, O. coriaceus Koch, O. hermsi } \\
\text { (primary epidemic vector unknown) }\end{array}$ & Unknown & $\mathrm{n} / \mathrm{a}$ \\
\hline Ehrlichia chafeensis, Ehrlichia ewingii & Ehrlichiosis & A. americanum, D. variabilis & $\begin{array}{l}24-50 \mathrm{~h} \\
\text { (A. phagocytophila) }\end{array}$ & $\begin{array}{l}{[33](12,24,30,36,50 \mathrm{~h}-\mathrm{C} 3 \mathrm{H} / \mathrm{HeJ} \text { mice); }} \\
{[35](24,48,72 \text {-mice })}\end{array}$ \\
\hline Ehrlichia muris & $\mathrm{n} / \mathrm{a}$ & I. scapularis & Unknown & $\mathrm{n} / \mathrm{a}$ \\
\hline Francisella tularensis & Tularemia & $\begin{array}{l}\text { A. americanum, D. andersoni, } \\
\text { D. variabilis*(also transmitted via aerosolized } \\
\text { contact with or ingestion of infected animals) }\end{array}$ & $48 \mathrm{~h}$ & $\begin{array}{l}{[41] \text { ( } 48,96,144 \text { h-saliva collected in }} \\
\text { capillary tube) }\end{array}$ \\
\hline Rickettsia 364D & $\mathrm{n} / \mathrm{a}$ & D. occidentalis & Unknown & $\mathrm{n} / \mathrm{a}$ \\
\hline Rickettsia montanensis & $\mathrm{n} / \mathrm{a}$ & D. variabilis & Unknown & $\mathrm{n} / \mathrm{a}$ \\
\hline Rickettsia parkeri & $\begin{array}{l}\text { Tidewater spotted fever, American boutonneuse fever, } \\
\text { Maculatum rickettsiosis }\end{array}$ & A. maculatum $^{* * *}$ & Unknown & $\mathrm{n} / \mathrm{a}$ \\
\hline Rickettsia rickettsii & Rocky Mountain spotted fever & D. variabilis, D. andersoni, Rh. sanguineus & $2-96 \mathrm{~h}$ & $\begin{array}{l}{[42](2 \mathrm{~h} \text { increments from } 2-18,24,36,48,} \\
>96 \mathrm{~h} \text {-guinea pigs, rabbits) }\end{array}$ \\
\hline Colorado tick fever virus & Colorado tick fever, mountain fever & D. andersoni & Unknown & $\mathrm{n} / \mathrm{a}$ \\
\hline Heartland virus & $\mathrm{n} / \mathrm{a}$ & A. americanum & Unknown & [43] (unknown attachment time-rabbits) \\
\hline Powassan virus & Powassan disease & D. variabilis, D. andersoni, I. scapularis * & $15-30 \mathrm{~min}$ & {$[14](15,30,60,180 \mathrm{~min}-\mathrm{BALB} / \mathrm{c} \mathrm{mice})$} \\
\hline Neurotoxin (possibly ixovotoxin) & Tick paralysis & $\begin{array}{l}\text { A. americanum, A. maculatum, D. andersoni, } \\
\text { D. variabilis, I. pacificus } \\
\text { (primary epidemic vector unknown) }\end{array}$ & $5-7$ days & [18] (human clinical case reports) \\
\hline carbohydrate galactose- $\alpha$-1,3-galactose & Meat allergies (alpha-gal syndrome) & A. americanum & Unknown & $\mathrm{n} / \mathrm{a}$ \\
\hline
\end{tabular}

* Transmission capacity verified in laboratory animals; ${ }^{* *}$ Pathogen not observed in all cases; ${ }^{* * *}$ A. maculatum did not become infected after feeding on cotton rats in the laboratory study [44]; **** Similar to Lyme disease. 


\subsection{Anaplasma phagocytophilum (Anaplasmosis)}

Anaplasmosis is caused by an intracellular bacterium infecting white blood cells. Anaplasma phagocytophilum (previously Ehrlichia phagocytophilum) is primarily transmitted by I. scapularis and Ixodes pacificus Cooley and Kohls. Transmission dynamics for anaplasmosis are not as well studied as are those for Lyme disease [35]. Anaplasma phagocytophilum inhabit the salivary glands of ticks more frequently than the midgut. One study exposed mice to nymphal I. scapularis infected with the NTN-1 strain of granulocytic ehrlichiae E. phagocytophilia (now A. phagocytophilum) [33], although the dose of pathogen imbibed by the ticks was not reported. Once ticks molted after blood feeding, they were held for two months prior to feeding on naïve mice. One of the 11 mice became infected with A. phagocytophilum after $24 \mathrm{~h}$ of tick attachment, zero of five at $30 \mathrm{~h}$ of attachment, eight of 12 at $36 \mathrm{~h}$ of attachment, and 11 of 13 after $50 \mathrm{~h}$ of attachment [33]. Another study assessed eight mice exposed to the NCH-1 strain of A. phagocytophilum-infected I. scapularis nymphs for $40 \mathrm{~h}$ (four mice) and $48 \mathrm{~h}$ (four mice) [32]. The same study showed that no mice exposed to ticks for $40 \mathrm{~h}$ were infected, while $100 \%$ of mice exposed for $48 \mathrm{~h}$ were infected with $A$. phagocytophilum [32], indicating that replication of $A$. phagocytophilum may be required for efficient transmission. The same study gave details about the pathogen dose imbibed by ticks. It is also unknown how long molted ticks were held prior to feeding on naïve mice for the transmission study. The two studies shown here [32,33] may have used different doses of the granulocytic agent to infect ticks (although these details are unclear) and this could have impacted the infection titer of the ticks that were used, hence, impacting the duration of tick attachment time required for transmission. Regardless, together both studies indicate that at least $24 \mathrm{~h}$ are required for transmission and transmission was increased dramatically after $48-50 \mathrm{~h}$. It is also possible for this pathogen to be transmitted transovarially [45].

\subsection{Babesia microti (Babesiosis)}

Babesia microti Babes is an apicomplexan protozoan parasite that causes babesiosis in vertebrates [34]. After an uninfected tick imbibes a Babesia-infected blood meal, ookinetes eventually escape the midgut into other tissues, where kinetes develop and invade the salivary glands [46]. An infectious tick vector transmits Babesia spp. sporozoites to vertebrate hosts and this pathogen can also be transmitted transstadially and transovarially in ticks [46]. This pathogen is primarily transmitted by I. scapularis [47].

Ticks feeding on mice co-infected with B. microti and B. burgdorferi were twice as likely to become infected with B. burgdorferi compared to B. microti; however, the study did not assess subsequent pathogen transmission rates [48]. Ticks were tested for pathogens up to six weeks after molting [48]. Babesia microti was transmitted to hamsters when I. scapularis was attached for $\geq 36 \mathrm{~h}$ [37]. The same study showed that $9 \%$ of hamsters were infected after $36 \mathrm{~h}$ of attachment, $17 \%$ infected after $48 \mathrm{~h}$, and $50 \%$ infected after a period of $54 \mathrm{~h}$ of attachment (mean \pm standard deviation; $9.5 \pm 4.3$ ticks/hamster). It is possible that the number of infected ticks infesting a vertebrate host and, hence, the number of parasites potentially invading that host, would complicate this analysis of duration of attachment time. Ideally, in a study to determine the duration of the attachment time required for transmission, each replicate would include examining the time it takes for one infected tick (with a known pathogen titer) to infect one naïve vertebrate host.

\subsection{Borrelia burgdorferi (Lyme Disease)}

Borrelia burgdorferi is transmitted by I. scapularis and I. pacificus [49]. Nymphal and adult ticks may transmit the pathogen to humans; however, I. scapularis nymphs are the most significant life stage involved in transmission because of their small size and spring-summer activity pattern [49]. Much attention has been paid to the time of tick attachment required to transmit B. burgdorferi and it is estimated that 300,000 human cases/year occur in the US [50]. Tick larvae or nymphs become infected after feeding on a spirochaetemic vertebrate reservoir host [50]. After ticks molt to the next life stage, 
spirochetes reside in the tick midgut and must disseminate to the salivary glands for transmission during feeding $[35,36]$. The number of spirochetes was examined in the midgut and salivary glands of I. scapularis nymphs during attachment to mice [36]. The mean numbers of B. burgdorferi spirochetes in infected tick midguts increased six-fold from pre-feeding to $48 \mathrm{~h}$ post-attachment [36]. For ticks that already had infected salivary glands, the mean number of spirochetes/pair of salivary glands rose by five-fold at $24 \mathrm{~h}$ and 21 -fold at $72 \mathrm{~h} \mathrm{[36].} \mathrm{The} \mathrm{same} \mathrm{studies} \mathrm{showed} \mathrm{that} \mathrm{the} \mathrm{fastest} \mathrm{increase} \mathrm{in}$ spirochete replication in the salivary glands occurred during $48-60 \mathrm{~h}$ post-attachment. These findings are consistent with laboratory animal studies where B. burgdorferi was rarely transmitted during the first $24 \mathrm{~h}$ of tick attachment [45]. Similarly, another study showed the transmission rate of B. burgdorferi to hamsters via I. scapularis increased over time (i.e., $24 \mathrm{~h} \mathrm{(7 \% ),} 48 \mathrm{~h} \mathrm{(36 \% ),} \geq 72 \mathrm{~h}(93 \%)$ ) [51]. To our knowledge, it is not possible for B. burgdorferi to be transmitted in ticks transovarially [52].

A study in New York State investigated tick attachment times (estimated by scutal index) in patients and examined incidence of erythema migrans (EM) and Lyme disease serology [53]. The odds of developing EM or seroconversion were 23 times higher for patients having a nymph or adult female I. scapularis attachment lasting $\geq 72 \mathrm{~h}$ compared to those with $<72 \mathrm{~h}$ of attachment. A relationship between the scutal index and patient reports of attachment time was only demonstrated in $49 \%$ of patients [53]. Studies using human tick bite patients highlight the difficulty of estimating tick attachment time versus risk of pathogen transmission. Patients often underestimate the duration of tick attachment because small ticks may not be detected immediately $[12,53,54]$.

A report from California asserting that three patients developed Lyme disease after less than $24 \mathrm{~h}$ of tick attachment raises questions about previous transmission studies [19]. The aforementioned study does not address potential issues, such as previous tick bites, and the duration of tick attachment as noted by critics of the study [55-57]. The same report also failed to diagnose Lyme disease using the Centers for Disease Control and Prevention's recommended two-tiered algorithm [58,59], leading others to question the accuracy of the tick attachment time as related to the development of Lyme disease [56,57]. It is possible that there is a difference in the attachment time required for transmission of $B$. burgdorferi by nymphs and adult females.

\subsection{Borrelia turicatae, B. hermsii (Tick-borne Relapsing Fever)}

Tick-borne relapsing fever (TBRF) was first recognized in the US in 1915 [60]. This illness results from infection by Borrelia spp. transmitted by soft ticks (Ornithodoros spp.). Borrelia hermsii Davis is transmitted to humans by Ornithodoros hermsi Wheeler [61,62]. Soft ticks attach to hosts for blood feeding for 10-45 min and spirochetes can be found in salivary glands three days after feeding on an infectious blood meal [34]. Mouse studies have shown transmission of $B$. hermsii within $30 \mathrm{~s}$ of attachment. Transmission of Borrelia turicatae Brumpt has been observed within $15 \mathrm{~s}$ after attachment [31]. The same study showed that, for blood meals interrupted after $15 \mathrm{~s}$, the transmission rate increased when three infected ticks (transmission rate $42-58 \%$ ) were placed on a single mouse, compared to when one or two infected ticks (transmission rate $20 \%$ ) were placed on a single mouse. This could indicate a greater pathogen dose being introduced into the host due to a greater number of co-feeding infectious ticks. It has also been indicated that $O$. turicatae may not transmit $B$. turicatae at every blood feeding, although the reason is unclear [38]. This may impact assessments of infection and transmission rates, if the tick is not able to consistently transmit the pathogen, even when the tick has previously transmitted the pathogen. It is not known whether or not B. turicatae and B. hermsii are transmitted transovarially.

\subsection{Borrelia mayonii (Borreliosis)}

Borrelia mayonii Pritt is a recently discovered species within B. burgdorferi senso lato complex and has been detected in field-collected I. scapularis [39,63]. From 2012-2014, six patients in the midwestern region of the US experienced Lyme borreliosis that was attributed to B. mayonii [63]. A vector competence study showed that transmission of $B$. mayonii was more common after infected $I$. 
scapularis were attached to mice for 72-96 h (3/5 mice became infected), compared to $24-48 \mathrm{~h}$ (1/6 mice became infected) of attachment [39]. In the same study, six infected ticks were feeding on each naïve mouse, hence, the amount of the pathogen being inoculated into each mouse by multiple ticks is expected to vary between replicates. This could have affected differences observed between mice. It is not known whether or not B. mayonii is transmitted transovarially.

\subsection{Borrelia miyamotoi (Borrelia myamotoi Disease, Borreliosis)}

Borrelia miyamotoi Fukunaga was isolated from field mice and I. persulcatus in Japan in 1994 [64] and subsequently reported in a US human in 2013 [65]. This pathogen is closely related to relapsing fever spirochetes and this may impact transmission. It has since been detected in US ticks from the midwest, northeast, south, and west [66]. Borrelia miyamotoi is transmitted by I. scapularis and I. pacificus. Studies have shown that its prevalence in four northeastern states (Connecticut, New Jersey, New York, Rhode Island) varied from 1.9-2.5\% of Ixodes spp. ticks sampled [67] and 0.7-1.7\% of I. pacificus ticks tested in California [68]. It has been found in $~ 12 \%$ of ticks tested in parts of Indiana [66] and transovarial transmission has been shown in I. scapularis [52] and I. ricinus [69]. The first cases of B. miyamotoi-infected humans were reported in Russia in 2011 [70,71]. A seroprevalence study of healthy residents of the Northeastern US showed (out of 639 samples), 25 (3.9\%) people were exposed to B. miyamotoi and were antibody-positive and 60 (9.4\%) were positive for B. burgdorferi antibodies [72]. An attachment study allowed transovarially-infected I. scapularis to blood feed on mice for 24, 48, 72, and 73-96 h [40]. The same study showed 10\% of mice infected with B. miyamotoi after a $24 \mathrm{~h}$ attachment time, 31\% infected at 48 h, 63\% infected by 72 h, and $73 \%$ of mice were infected by $73-96$ h.

\subsection{Francisella tularensis (Tularemia)}

Francisella tularensis bacteria cause tularemia and Dermacentor andersoni Stiles is the primary arthropod vector of this pathogen to humans; however, Amblyomma americanum L., D. variabilis [73], and Haemaphysalis leporispalustris Packard are also potential vectors [34]. The pathogen can also be transmitted mechanically by deer flies, horse flies, or mosquitoes, or via aerosol/ingestion when processing/eating infected animal tissues [34,73]. Francisella tularensis can be transtadially transmitted in D. variabilis [41] and transtadially and transovarially transmitted (at a low level) in A. americanum [41]. However, transovarial transmission is considered uncommon in nature [73]. Amblyomma americanum either inoculated with or fed F. tularensis via capillary tube transmitted infectious saliva into capillary tubes collected two days post-inoculation [41]. However, these ticks were injected with a secretagogue (hormone-releasing compound) to induce salivation into capillary tubes, hence, this unnatural stimulus may have impacted the time for pathogen transmission. In the same study, mice injected with infectious tick saliva became infected; however, transmission directly from ticks to mice was not tested. In a separate study, four to 11 days after placement on infected Swiss Webster mice, D. variabilis were assessed for transmission efficiency of three different strains of F. tularensis [74]. The transmission rate for fully blood-fed D. variabilis was 14\% for F. tularensis holarctica (type B; strain KY99-3387), but 0\% for two other F. tularensis tularensis strains (MA00-2987; WY96-3418) [74]. In the aforementioned study, ticks were allowed to feed to repletion and duration of tick attachment time required for initial transmission was not assessed.

\subsection{Rickettsia rickettsii (Rocky Mountain Spotted Fever)}

RMSF is caused by $R$. rickettsii transmitted to humans primarily by adult $D$. variabilis and $D$. andersoni. However, R. rickettsii has also been found in field-collected Rhipicephalus sanguineus Latreille [75]. Others also report R. rickettsii-infected, A. americanum, Dermacentor parumapertus Neumann, and H. leporispalustris [76-78].

It takes 15-20 min for a tick to become firmly attached to its host [78]. It has been shown that hosts having $R$. rickettsii-infected ticks attached for 10-20 h consistently became infected with RMSF [79]. Reports show that infectious ticks must be attached for 6-10 h before $R$. rickettsii is transmitted 
via saliva [80-82]. Another report shows that guinea pigs exposed to R. rickettsii-infected unfed Amblyomma aureolatum Pallas nymphs or adults (larvae had previously been infected by feeding on an infected guinea pig) for $\leq 10 \mathrm{~h}$ did not become infected [42]. The study did not report the degree of blood feeding (engorgement indices) achieved by the ticks ( 10 nymphal ticks or 1 adult tick per guinea pig) but that the countdown began after the first tick became fully attached. The same study showed all guinea pigs became infected after a $14 \mathrm{~h}$ (initially) unfed nymph or adult tick exposure period. However, partially-fed A. aureolatum adults (male and female ticks fed upon rabbits for $48 \mathrm{~h}$ prior to feeding on guinea pigs) transmitted $R$. rickettsii to guinea pigs after only ca. $10 \mathrm{~min}$ [42]. It is during this blood feeding period [81], and/or when ticks are incubated at warm temperatures $\left(37^{\circ} \mathrm{C}\right)$ for

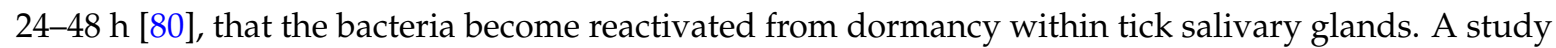
evaluating transcriptional changes in $R$. rickettsii contained in A. aureolatum showed five times more genes (e.g., type IV secretion system and antioxidant enzymes were upregulated) exhibited changes due to blood feeding versus environmental temperature increases alone, further supporting an increase in the bacterial load due to blood feeding [83]. This pathogen can be transovarially transmitted [84].

\subsection{Heartland Virus}

Heartland virus (family Bunyaviridae, genus Phlebovirus) was first reported in humans in 2012 and is primarily found in Missouri [85]. Amblyomma americanum nymphs have been found infected with Heartland virus; however, no vertebrate reservoir has been confirmed [86]. A study infected larval and nymphal $A$. americanum by immersing their bodies in a solution of Heartland virus prior to allowing the ticks to feed on rabbits [43]. The same study showed transovarial and transstadial transmission of Heartland virus, and also the transmission to other ticks through co-feeding. However, no information was provided about the duration of attachment required for transmission [43].

\subsection{Powassan Virus}

Powassan virus has been isolated from D. andersoni, Ixodes cookei Packard, Ixodes marxi Banks, I. scapularis, and Ixodes spinipalpus Hadwin and Nuttall $[34,86,87]$. POWV-infected I. scapularis nymphs transmitted the virus to mice in as little as $15 \mathrm{~min}$ (63\% transmission rate), with maximum transmission efficiency (83\%) achieved after $180 \mathrm{~min}$ of attachment [14]. It is possible that ticks transmitted POWV faster than within $15 \mathrm{~s}$ since that was the first time point that was checked. In the same study, infected mice were infested by multiple larval ticks (i.e., 23 mice were infested by 31 POWV-infected ticks) and ticks (tested after blood feeding) had a range of viral titers (infected larva had a titer range ca. $0.5-1.5 \log _{10}$ plaque-forming units/tick; after molting, infected nymphal ticks had a titer range ca. $0.25-5.5 \log _{10}$ plaque-forming units/tick). One naïve mouse did not become infected after being fed upon by two infected nymphal ticks [14]. This indicates transmission does not always occur and may be dependent on virus dose inoculated by the potential vector. It is possible for Powassan virus to be transmitted transovarially [88].

\subsection{Neurotoxin (Tick Paralysis)}

Tick paralysis is caused by a neurotoxin transmitted in tick saliva during attachment by several hard and soft tick species [89]. Ixovotoxin (related to tick egg production) may be the substance responsible for tick paralysis [90]. The tick must be attached for two to six days for this toxin to take effect [91]. Toxin production coincides with paralytic symptoms and continued tick feeding appears to accelerate toxin production, accounting for rapid progression of clinical signs [90,92]. In the US, ticks that have been implicated in tick paralysis are $D$. andersoni and $D$. variabilis. It is also associated with A. americanum, Amblyomma maculatum Koch, I. pacificus, and I. scapularis.

\subsection{Galactose- $\alpha-1,3-$ Galactose (Mammalian Meat Allergy-Alpha-Gal Syndrome)}

Alpha-gal syndrome is caused in humans when, during blood feeding, ticks expectorate (in saliva) the carbohydrate galactose- $\alpha-1,3$-galactose (alpha-gal) and antibodies are produced in the human [93]. 
If humans with alpha-gal antibodies ingest mammalian meat, allergic symptoms may result. In the US, alpha-gal syndrome has become most common in the southeast [93] and meat allergies (e.g., beef, lamb, pork, venison, cow milk) are associated with A. americanum prevalence [94]. It is unknown how long a tick must be attached in order for the alpha-gal sensitivity to occur. It is thought that meat allergies would lessen over time if further tick bites were prevented [93]; however, more research must be done to verify this.

\section{Discussion}

Unlike mosquito-borne viruses that rely solely on the transfer of infectious saliva for propagation in vertebrate hosts, hard and soft ticks can transmit pathogens (viruses, bacteria, protozoa) via saliva, regurgitation of gut contents, and also via the cement-like secretion (hard ticks) used to secure itself to the host [26]. Tick-borne diseases are an important health threat that continues to impact public health worldwide. The impact of tick-borne pathogens may be more extensive than currently understood due to factors such as nonspecific symptoms experienced during other illnesses, lack of adequate surveillance systems, and climatic variables impacting tick and animal behaviors $[95,96]$. Furthermore, emerging and re-emerging tick-borne pathogens necessitate the push for further research in this area to protect public health.

For tick-pathogen systems where published data exists on duration of tick attachment times, variation was observed between different pathogens and most assessments were conducted on nonhuman vertebrates, such as rodents. For hard ticks, the duration of attachment required for transmission of the virus evaluated here was shorter (15-30 min-POWV) than for bacteria (4-96 h-multiple species evaluated), protozoan (7-18 days-Babesia microti), and neurotoxin (5-7 days). For soft ticks, we found information on the duration of attachment time (15 s-30 min) required for transmission of Borrelia turicata and this was a relatively short time period (similar to POWV transmission by hard ticks) that related to the nature of soft ticks to have brief blood feeding periods, compared to longer feeding periods required by hard ticks.

Most studies involve placing multiple ticks on multiple rodents, rather than a single tick on a single rodent, hence, adding further complexity to the comparison of transmission rates and duration of attachment time required for transmission between studies. Multiple ticks may be simultaneously delivering different pathogen doses to the host, therefore, in these cases, the host infection rate cannot be tied to one dose delivered by one tick. Furthermore, some studies assess the bacteremia or viremia in ticks that fed upon mice, but others determine only the status of infection in mice that were fed upon and not ticks. Rarely do studies determine the titer of both tick and host, making it difficult to make a connection between the pathogen dose delivered by the tick and the infection rate of the host. We expect further variation to exist in vector competence due to the pathogen dose transmitted by ticks to hosts, biological and/or environmental conditions, pathogen/vector/host species and population, age of victims, and other unidentified factors. In order to improve species- and population-specific risk assessments of pathogen transmission to humans and other animals, more focused experimentally-controlled vector competence research is needed for tick-borne pathogens. Laboratory experiments are not always an indication of field conditions; however, laboratory vector competence studies could provide a basis and starting point for field assessments of risk.

We could not find any published tick attachment time data for the following pathogens: Southern tick associated rash illness, Borrelia parkeri Davis, Coxiella burnetii, Ehrlichia chaffeensis Anderson, Ehrlichia ewingii Ewing, Ehrlichia muris Wen, Rickettsia 364D, Rickettsia montanensis Lackman, Rickettsia parkeri Lackman, and Colorado tick fever virus. Workers in outdoor occupations, such as forestry and the military, as well as those spending time outdoors participating in recreational activities, should be aware of the relationship between tick attachment time and the potential for pathogen transmission. Tick exposure does not always result in pathogen transmission and disease; however, the health threat exists and individuals should be aware of how to prevent and/or mitigate these risks. 


\section{Conclusions}

The current analysis of published literature reveals knowledge gaps in the duration of tick feeding time required for pathogen transmission. For tick-pathogen systems where published data exists on duration of tick attachment times, variation was observed between systems and most evaluations were conducted on nonhuman vertebrates. We expect further variation for different pathogen doses, biological and/or environmental conditions, pathogen/vector/host species and population, age of victims, and other unidentified factors. More research is needed to clarify tick vector competence for pathogens, duration of tick attachment time required to transmit pathogens, tick species able to transmit multiple pathogens, etc. to improve risk assessment for this potentially underestimated public health threat.

Acknowledgments: This research did not receive any specific grant from funding agencies in the public, commercial, or not-for-profit sectors. The authors thank two anonymous reviewers for their comments that improved the manuscript.

Author Contributions: Ricky Langley conceived and designed the review. Stephanie L. Richards, Ricky Langley, Charles S. Apperson, and Elizabeth Watson analyzed the data. Stephanie L. Richards wrote the paper. Stephanie L. Richards, Ricky Langley, Charles S. Apperson, and Elizabeth Watson edited the paper.

Conflicts of Interest: The authors declare no conflict of interest.

\section{References}

1. Merten, H.; Durden, L. A state-by-state survey of ticks recorded from humans in the United States. J. Vector Ecol. 2000, 25, 102-113. [PubMed]

2. Spach, D.; Liles, W.C.; Campbell, G.; Quick, R.; Anderson, D.; Fritsche, T. Tick-borne diseases in the United States. N. Engl. J. Med. 1993, 329, 936-947. [CrossRef] [PubMed]

3. Dworkin, M.; Schwan, T.; Anderson, D.; Borchardt, S. Tick-borne relapsing fever. Infect. Dis. Clin. N. Am. 2008, 22, 449-468. [CrossRef] [PubMed]

4. Centers for Disease Control and Prevention. Tickborne Diseases of the US. Available online: http:/ /www. cdc.gov/ticks/diseases/index.html (accessed on 29 March 2017).

5. Jurke, A.; Bannert, N.; Brehm, K.; Fingerle, V.; Kempf, V.A.; Kompf, D.; Lunemann, M.; Mayer-Schill, A.; Neidrig, M.; Nockler, K.; et al. Serological survey of Bartonella spp.; Borrelia burgdorferi, Brucella spp.; Coxiella burnettii, Francisella tularensis, Leptospira spp.; Echinococcus, Hanta-, TBE- and XMR-virus infection in employees of two forestry enterprises in North Rhine Westphalia, Germany, 2011-2013. Int. J. Med. Microbiol. 2015, 305, 652-662. [PubMed]

6. Chmielewska-Badora, J.; Moniuszko, A.; Zukiewicz-Sobczak, W.; Zwolinski, J.; Piatek, J.; Pancewicz, S. Serological survey in persons occupationally exposed to tick-borne pathogens in cases of co-infections with Borrelia burgdorferi, Anaplasma phagocytophilum, Bartonella spp. and Babesia microti. Ann. Agric. Environ. Med. 2012, 19, 271-274. [PubMed]

7. Adjemian, J.; Weber, I.B.; McQuiston, J.; Griffith, K.S.; Mead, P.S.; Nicholson, W.; Roche, A.; Schriefer, M.; Fisher, M.; Kosoy, O.; et al. Zoonotic infections among employees from Great Smoky Mountains and Rocky Mountain National Parks. Vector Borne Zoonotic Dis. 2012, 12, 922-931. [CrossRef] [PubMed]

8. Faulde, M.K.; Rutenfranz, M.; Hepke, J.; Rogge, M.; Gorner, A.; Keth, A. Human tick infestation pattern, tick-bite rate, and associated Borrelia burgdorferi s.l. infection risk during occupational tick exposure at the Seedorf military training area, northwestern Germany. Ticks Tick Borne Dis. 2014, 5, 594-599. [CrossRef] [PubMed]

9. Vaughn, M.F.; Funkhouser, S.W.; Lin, F.C.; Fine, J.; Juliano, J.J; Apperson, C.S.; Meshnick, S.R. Long-lasting permethrin impregnated uniforms: A randomized-controlled trial for tick bite prevention. Am. J. Prev. Med. 2014, 46, 473-480. [CrossRef] [PubMed]

10. Londono-Renteria, B.; Patel, J.C.; Vaughn, M.; Funkhauser, S.; Ponnusamy, L.; Grippin, C.; Jameson, S.B.; Apperson, C.S.; Mores, C.N.; Wesson, D.M.; et al. Long-lasting permethrin-impregnated clothing protects against mosquito bites in outdoor workers. Am. J. Trop. Med. Hyg. 2015, 93, 869-874. [CrossRef] [PubMed]

11. Goethert, H.; Telford, S. Quantum of infection of Francisella tularensis in host seeking Dermacentor variabilis. Ticks Tick-Borne Dis. 2010, 1, 66-68. [CrossRef] [PubMed] 
12. Wilhelmsson, P.; Linblom, P.; Fryland, L.; Nyman, D.; Jaenson, T.G.T.; Forsberg, P.; Lindgren, P.E. Ixodes ricinus ticks removed from humans in Northern Europe: Seasonal pattern of infestation, attachment sites and duration of feeding. Parasites Vectors 2013, 6, 362. [CrossRef] [PubMed]

13. Lindbloom, P.; Wilhelmsson, P.; Fryland, L.; Sjowall, J.; Haglund, M.; Matussek, A.; Ernerudh, J.; Vene, S.; Nyman, D.; Andreassen, A.; et al. Tick-borne encephalitis virus in ticks detached from humans and follow-up of serological and clinical response. Ticks Tick-Borne Dis. 2014, 5, 21-28. [CrossRef] [PubMed]

14. Ebel, G.; Kramer, L. Short report: Duration of tick attachment required for transmission of Powassan virus by deer ticks. Am. J. Trop. Med. Hyg. 2004, 71, 268-271. [PubMed]

15. Goodman, J.; Dennis, D.T.; Sonenshine, D.E. (Eds.) Tick-Borne Diseases of Humans; ASM Press: Washington, DC, USA, 2005.

16. De la Fuente, J.; Antunes, S.; Bonnet, S.; Cabezas-Cruz, A.; Domingos, A.G.; Estada-Pena, A.; Johnson, N.; Kocan, K.M.; Mansfield, K.L.; Nijhof, A.M.; et al. Tick-pathogen intereactions and vector competence: Identification of molecular drivers for tick-borne disease. Front. Cell. Infect. Microbiol. 2017, 7, 114. [CrossRef] [PubMed]

17. Peavey, C.A.; Lane, R.S. Transmission of Borrelia burgdorferi by Ixodes pacificus nymphs and reservoir competence of deer mice (Peromyscus maniculatus) infected by tick bite. J. Parasitol. 1995, 81, 175-178. [CrossRef] [PubMed]

18. Dworkin, M.; Shoemaker, P.C.; Anderson, D.E. Tick paralysis: 33 human cases in Washington state, $1946-1996$. Clin. Infect. Dis. 1999, 29, 1435-1439. [CrossRef] [PubMed]

19. Hynote, E.D.; Mervine, P.C.; Stricher, R.B. Clinical evidence for rapid transmission of Lyme disease following a tick bite. Diagn. Microbiol. Infect. Dis. 2012, 72, 188-192. [CrossRef] [PubMed]

20. Yeh, M.T.; Bak, J.M.; Hu, R.; Nicholson, M.C.; Kelly, C.; Mather, T.N. Determining the duration of Ixodes scapularis (Acari: Ixodidae) attachment to tick-bite victims. J. Med. Entomol. 1995, 32, 853-858. [CrossRef] [PubMed]

21. Oliver, J.H.; Al-Ahmadi, Z.; Osburn, R.L. Reproduction in ticks (Acari: Ixodoidea). 3. Copulation in Dermacentor occidentalis Marx and Haemaphysalis leporispalustris (Packard) (Ixodidae). J. Parasitol. 1974, 60, 499-506. [CrossRef] [PubMed]

22. Kaufman, W.R. Gluttony and sex in female Ixodid ticks: How do they compare to other blood-sucking arthropods? J. Insect Phys. 2007, 53, 264-273. [CrossRef] [PubMed]

23. Kaufman, W.R. Tick-host interaction: A synthesis of current concepts. Parasitol. Today 1989, 5, 47-56. [CrossRef]

24. Pappas, P.J.; Oliver, J.H., Jr. Reproduction in ticks (Acari: Ixodoidea). 2. Analysis of the stimulus for rapid and complete feeding of female Dermacentor variabilis (Say). J. Med. Entomol. 1972, 9, 47-50. [CrossRef] [PubMed]

25. Sonenshine, D.E.; Roe, R.M. (Eds.) Biology of Ticks, 2nd ed.; Oxford University Press: Oxford, UK, $2014 ;$ p. 93.

26. Alekseev, A.N.; Burenkova, L.A.; Vasilieva, I.S.; Dubinina, H.V.; Chunikhin, S.P. Preliminary studies on virus and spirochete accumulation in the cement plug of Ixodid ticks. Exp. Appl. Acarol. 1996, 20, 713-723. [CrossRef] [PubMed]

27. Sonenshine, D.E. (Ed.) Biology of Ticks, 1st ed.; Oxford University Press: New York, NY, USA; Oxford, UK, 1991.

28. Needham, G.R. Evaluation of five popular methods for tick removal. Pediatrics 1985, 75, 997-1002. [PubMed]

29. Crippa, M.; Rais, O.; Gern, L. Investigations on the mode and dynamics of transmission and infectivity of Borrelia burgdorferi sensu stricto and Borrelia afzelii in Ixodes ricinus ticks. Vector Borne Zoonotic Dis. 2002, 2, 3-9. [CrossRef] [PubMed]

30. Diehl, P.A.; Aeschlimann, A.; Obenchain, F.D. Tick reproduction: oogenesis and oviposition. In Physiology of Ticks; Obenchain, F.D., Galun, R., Eds.; Pergamon Press: Elmsford, NY, USA, 1982; pp. 277-350.

31. Boyle, W.; Wilder, H.; Lawrence, A.; Lopez, J. Transmission dynamics of Borrelia turicatae from the arthropod vector. PLoS Negl. Trop. Dis. 2014, 8, e2767. [CrossRef] [PubMed]

32. Hodzic, E.; Fish, D.; Maretzki, C.M.; De Silva, A.M.; Feng, S.; Barthold, S.W. Acquisition and transmission of the agent of human granulocytic ehrlichiosis by Ixodes scapularis ticks. J. Clin. Microbiol. 1998, 36, 3574-3578. [PubMed]

33. Katavolos, P.; Armstrong, P.M.; Dawson, J.E.; Telford, S.R. Duration of tick attachment required for transmission of granulocytic ehrlichiosis. J. Infect. Dis. 1998, 177, 1422-1425. [CrossRef] [PubMed] 
34. Service, M.W. The Encyclopedia of Arthropod-Transmitted Infections; CABI Publishing: New York, NY, USA, 2001.

35. Des Vignes, F.; Piesman, J.; Heffernan, R.; Schulze, T.L.; Stafford, K.C.; Fish, D. Effect of tick removal on transmission of Borrelia burgdorferi and Ehrlichia phagocytophila by Ixodes scapularis nymphs. J. Infect. Dis. 2001, 183, 773-778. [CrossRef] [PubMed]

36. Piesman, J.; Schneider, B.S.; Zeidner, N.S. Use of quantitative PCR to measure density of Borrelia burgdorferi in the midgut and salivary glands of feeding tick vectors. J. Clin. Microbiol. 2001, 39, 4145-4148. [CrossRef] [PubMed]

37. Piesman, J.; Spielman, A. Human babesiosis on Nantucket Island: Prevalence of Babesia microti in ticks. Am. J. Trop. Med. Hyg. 1980, 29, 742-746. [PubMed]

38. Davis, G.E. Ornithodorus turicata: The males; feeding and copulation habits, fertility, span of life, and the transmission of relapsing fever spirochetes. Public Health Rep. 1941, 56, 1799-1802. [CrossRef]

39. Dolan, M.C.; Hoigaard, A.; Hoxmeier, J.C.; Replogle, A.J.; Respicio-Kingry, L.B.; Sexton, C.; Williams, M.A.; Pritt, B.S.; Schreifer, M.E.; Eisen, L. Vector competence of the blacklegged tick, Ixodes scapularis, for the recently recognized Lyme borreliosis spirochete Candidatus Borrelia mayonii. Ticks Tick-Borne Dis. 2016, 7, 665-669. [CrossRef] [PubMed]

40. Breuner, N.E.; Dolan, M.C.; Replogle, A.J.; Sexton, C.; Hojgaard, A.; Boegler, K.A.; Clark, R.J.; Eisen, L. Transmission of Borrelia miyamotoi sensu lato relapsing fever group spirochetes in relation to duration of attachment by Ixodes scapularis nymphs. Ticks Tick-Borne Dis. 2017. [CrossRef]

41. Mani, R.J.; Metcalf, J.A.; Clinkenbeard, K.D. Amblyomma americanum as a bridging vector for human infection with Francisella tularensis. PLoS ONE 2015, 10, e0130513. [CrossRef] [PubMed]

42. Saraiva, D.G.; Soares, H.S.; Sores, J.F.; Labruna, M.B. Feeding period required by Amblyomma aureolatum ticks for transmission of Rickettsia rickettsii to vertebrate hosts. Emerg. Infect. Dis. 2014, 20, 1504-1510. [CrossRef] [PubMed]

43. Godsey, M.S.; Savage, H.M.; Burkhalter, K.L.; Bosco-Lauth, A.M.; Delorey, M.J. Transmission of Heartland virus (Bunyaviridae: Phlebovirus) by experimentally infected Amblyomma americanum (Acari: Ixodidae). J. Med. Entomol. 2016, 53, 1226-1233. [CrossRef] [PubMed]

44. Moraru, G.M.; Goddard, J.; Paddock, C.D.; Varela-Stokes, A. Experimental infection of cotton rats and bobwhite quail with Rickettsia parkeri. Parasites Vectors 2013, 15, 70-75. [CrossRef] [PubMed]

45. Baldridge, G.D.; Scoles, G.A.; Burkhardt, N.Y.; Schloeder, B.; Kurtti, T.J.; Munderloh, U.G. Transovarial transmission of Francisella-like endosymbionts and Anaplasma phagocytophilum variants in Dermacentor albopictus (Acari: Ixodidae). J. Med. Entomol. 2009, 46, 625-632. [CrossRef] [PubMed]

46. Chauvin, A.; Moreau, E.; Bonnet, S.; Plantard, O.; Malandrin, L. Babesia and its hosts: Adaptation to long-lasting interactions as a way to achieve efficient transmission. Vet. Res. 2009, 40, 37-45. [CrossRef] [PubMed]

47. Knapp, K.L.; Rice, N.A. Human coinfection with Borrelia burgdorferi and Babesia microti in the United States. J. Parasitol. Res. 2015, 2015, 587131. [CrossRef] [PubMed]

48. Mather, T.N.; Telford, S.R.; Moore, S.I.; Spielman, A. Borrelia burgdorferi and Babesia microti: Efficiency of transmission from reservoirs to vector ticks (Ixodes dammini). Exp. Parasitol. 1990, 70, 55-61. [CrossRef]

49. Stanek, G.; Wormser, G.P.; Gray, J.; Strle, F. Lyme borreliosis. Lancet 2012, 379, 461-473. [CrossRef]

50. Centers for Disease Control and Prevention. Lyme Disease Data. 2017. Available online: http://www.cdc. gov/lyme/stats/index.html (accessed on 29 March 2017).

51. Piesman, J.; Mather, T.N.; Sinsky, R.J.; Spielman, A. Duration of tick attachment and Borrelia burgdorferi transmission. J. Clin. Microbiol. 1987, 25, 557-558. [PubMed]

52. Rollend, L.; Fish, D.; Childs, J.E. Transovarial transmission of Borrelia spirochetes by Ixodes scapularis: A summary of the literature and recent observations. Ticks Tick-Borne Dis. 2013, 4, 46-51. [CrossRef] [PubMed]

53. Sood, S.K.; Salzman, M.B.; Johnson, B.J.B.; Happ, C.M.; Feig, K.; Carmody, L.; Rubin, L.G.; Hilton, E.; Piesman, J. Duration of tick attachment as a predictor of the risk of Lyme disease in an area in which Lyme disease is endemic. J. Infect. Dis. 1997, 175, 996-999. [CrossRef] [PubMed]

54. Hofhuis, A.; Herremans, T.; Notermans, D.W.; Sprong, H.; Fonville, M.; van der Giessen, J.W.; van Pelt, W. A prospective study among patients presenting at the general practitioner with a tick bite or erythema migrans in the Netherlands. PLoS ONE 2013, 8, e64361. [CrossRef] [PubMed] 
55. Piesman, J.; Gray, J. Letter in response to the Hynote article. Diagn. Microbiol. Infect. Dis. 2012, 73, $103-104$. [CrossRef] [PubMed]

56. Sugar, A.M. Letter in response to the Hynote article. Diagn. Microbiol. Infect. Dis. 2012, 73, 103. [CrossRef] [PubMed]

57. Binnicker, M.J.; Theel, E.S.; Pritt, B.S. Lack of evidence for rapid transmission of Lyme disease following a tick bite. Diagn. Microbiol. Infect. Dis. 2012, 73, 102-103. [CrossRef] [PubMed]

58. Wormser, G.P.; Dattwyler, R.J.; Shapiro, E.D.; Halperin, J.J.; Steere, A.C.; Klempner, M.S.; Krause, P.J.; Bakken, J.S.; Strle, F.; Stanek, G.; et al. The clinical assessment, treatment and prevention of Lyme disease, human granulocytic anaplasmosis and babesiosis: Clinical practice guidelines by the Infectious Diseases Society of America. Clin. Infect. Dis. 2006, 43, 1089-1134. [CrossRef] [PubMed]

59. Centers for Disease Control and Prevention. Recommendations for test performance and interpretation from the second national conference on serological diagnosis of Lyme disease. MMWR 1995, 44, 590-591.

60. Meader, C.N. Five cases of relapsing fever originating in Colorado, with positive blood findings in two. Colorado Med. 1915, 12, 365-368.

61. Schwan, T.; Raffel, S.; Schrumpf, M.; Porcella, S. Diversity and distribution of Borrelia hermsii. Emerg. Infect. Dis. 2007, 13, 436-442. [CrossRef] [PubMed]

62. Centers for Disease Control and Prevention. Tick-Borne Relapsing Fever. Available online: http://www.cdc. gov/relapsing-fever/ (accessed on 29 March 2017).

63. Pritt, B.S.; Mead, P.S.; Hoang Johnson, D.K.; Neitzel, D.F.; Respicio-Kingry, L.B.; Davis, J.P.; Schiffman, E.; Sloan, L.M.; Schriefer, M.E.; Replogle, A.J.; et al. Identification of a novel pathogenic Borrelia species causing Lyme borreliosis with unusually high spirochaetaemia: A descriptive study. Lancet Infect. Dis. 2016, 16, 556-564. [CrossRef]

64. Fukunaga, M.; Takahashi, Y.; Tsuruta, Y.; Matsushita, O.; Ralph, D.; McClelland, M.; Nakao, M. Genetic and phenotypic analysis of Borrelia miyamotoi sp. nov. isolated from the Ixodid tick Ixodes persulcatus, the vector for Lyme disease in Japan. Int. J. Syst. Bacteriol. 1995, 45, 804-810. [CrossRef] [PubMed]

65. Gugliotta, J.; Goethert, H.; Berardi, V.; Telford, S. Meningoencephalitis from Borrelia miyamotoi in an immunocompromised patien. NEJM 2013, 368, 240-245. [CrossRef] [PubMed]

66. Crowder, C.; Carolan, H.; Rounds, M.; Honig, V.; Mothes, B.; Haag, H.; Nolte, O.; Luft, B.; Grubhoffer, L.; Ecker, D.; et al. Prevalence of Borrelia miyamotoi in Ixodes ticks in Europe and the United States. Emerg. Infect. Dis. 2014, 20, 1678-1682. [CrossRef] [PubMed]

67. Scoles, G.; Papero, M.; Beati, L.; Fish, D. A relapsing fever group spirochete transmitted by Ixodes scapularis ticks. Vector Borne Zoon. Dis. 2001, 1, 21-34. [CrossRef] [PubMed]

68. Munn, J.R.; Eisen, R.; Eisen, L.; Lane, R. Detection of Borrelia miyamotoi senso lato relapsing-fever group spirochete from Ixodes pacificus in California. J. Med. Entomol. 2006, 43, 120-123. [CrossRef]

69. Van Duijvendijk, G.; Coipan, C.; Wagemakers, A.; Fonville, M.; Ersoz, J.; Oei, A.; Foldvari, G.; Hovius, J.; Takken, W.; Sprong, H. Larvae of Ixodes ricinus transmit Borrelia afzelii and B. miyamotoi to vertebrate hosts. Parasites Vectors 2016, 9, 97. [CrossRef] [PubMed]

70. Platonov, A.; Karan, L.; Kolyasnikova, N.; Makhneva, N.; Toporkova, M.; Maleev, V.; Fish, D.; Krause, P. Humans infected with relapsing fever spirochete Borrelia miyamotoi, Russia. Emerg. Infect. Dis. 2011, 17, 1816-1823. [CrossRef] [PubMed]

71. Sarkysan, D.; Platonov, A.; Karan, L.; Malinin, I.; Khalitova, L.; Shakhov, V.; Dudarev, M.; Malinin, M.; Maleev, V. Clinical presentation of "new" tick-borne borreliosis caused by Borrelia miyamotoi. Terapevticheskii Arkhiv 2012, 84, 34-41.

72. Krause, P.; Narasimhan, S.; Wormser, G.; Barbour, A.; Platonov, A.; Brancato, J.; Lepore, T.; Dardick, K.; Mamula, M.; Rollend, L.; et al. Borrelia miyamotoi sensu lato seroreactivity and seroprevalence in the northeastern United States. Emerg. Infect. Dis. 2014, 20, 1183-1190. [PubMed]

73. Peterson, J.M.; Mead, P.S.; Schriefer, M.E. Francisella tularensis: An arthropod-borne pathogen. Vet. Res. 2009, 40, 2008045. [CrossRef] [PubMed]

74. Reese, S.M.; Petersen, J.M.; Sheldon, S.W.; Dolan, M.C.; Dietrich, C.; Piesman, J.; Eisen, R.J. Transmission efficiency of Francisella tularensis by adult American dog ticks (Acari: Ixodidae). J. Med. Entomol. 2011, 48, 884-890. [CrossRef] [PubMed] 
75. Demma, L.J.; Traeger, M.S.; Nicholson, W.L.; Paddock, C.D.; Blau, D.M.; Eremeeva, M.A.; Dasch, G.A.; Levin, M.L.; Singleton, J.; Zaki, S.R.; et al. Rocky Mountain spotted fever from an unexpected tick vector in Arizona. NEJM 2005, 353, 587-594. [CrossRef] [PubMed]

76. Burgdorfer, W. A review of Rocky Mountain spotted fever (tick-borne typhus), its agent, and its tick vectors in the United States. J. Med. Entomol. 1975, 12, 269-278. [CrossRef] [PubMed]

77. Parola, P.; Paddock, C.D.; Raoult, D. Tick-borne rickettsioses around the world: Emerging diseases challenging old concepts. Clin. Microbiol. Rev. 2005, 18, 719-756. [CrossRef] [PubMed]

78. Berrada, Z.L.; Goethert, H.K.; Cunningham, J.; Telford, S.R., III. Rickettsia rickettsii (Rickettsiales: Rickettsiaceae) in Amblyomma americanum (Acari: Ixodidae) from Kansas. Vector Borne Zoon. Dis. 2011, 48, 461-467. [CrossRef]

79. Ricketts, H.T. Contributions to Medical Science; University of Chicago Press: Chicago, IL, USA, 1911.

80. Hayes, S.F.; Burgdorfer, W. Reactivation of Rickettsia rickettsii in Dermacentor andersoni ticks: An ultrastructural analysis. Infect. Immun. 1982, 37, 779-785. [PubMed]

81. Chen, L.F.; Sexton, D.J. What's new in Rocky Mountain spotted fever? Infect. Dis. Clin. N. Am. 2008, 22, 415-432. [CrossRef] [PubMed]

82. Salinas, L.J.; Greenfield, R.A.; Little, S.E.; Voskuhl, G.W. Tick-borne infections in the southern United States. Am. J. Med. Sci. 2010, 340, 194-201. [CrossRef] [PubMed]

83. Galletti, M.F.; Fujita, A.; Nishiyama, M.Y.; Malossi, C.D.; Pinter, A.; Soares, J.F.; Daffre, S.; Labruna, M.B.; Fogaca, A.C. Natural blood feeding and temperature shift modulate the global transcriptional profile of Rickettsia rickettsii infecting its tick vector. PLOS ONE 2013, 8, e77388. [CrossRef] [PubMed]

84. Levin, M.L.; Zemtsova, G.E.; Killmaster, L.F.; Snellgrove, A.; Schumacher, L.B.M. Vector competence of Amblyomma americanum (Acari: Ixodidae) for Rickettsia rickettsii. Ticks Tick-Borne Dis. 2017. [CrossRef] [PubMed]

85. McMullen, L.K.; Folk, S.M.; Kelley, A.J.; MacNeil, A.; Goldsmith, C.S.; Metcalfe, M.G.; Batten, B.C.; Albarino, C.G.; Zaki, S.R.; Rollin, P.E.; et al. A new phlebovirus associated with severe febrile illness in Missouri. N. Eng. J. Med. 2012, 367, 834-841. [CrossRef] [PubMed]

86. Wormser, G.P.; Pritt, B. Update and commentary on four emerging tick-borne infections. Infect. Dis. Clin. N. Am. 2015, 29, 371-381. [CrossRef] [PubMed]

87. Romero, J.R.; Simonsen, K.A. Powassan encephalitis and Colorado tick fever. Infect. Dis. Clin. N. Am. 2008, 22, 545-559. [CrossRef] [PubMed]

88. Costero, A.; Grayson, M.A. Experimental transmission of Powassan virus (Flaviviridae) by Ixodes scapularis ticks (Acari: Ixodidae). Am. J. Trop. Med. Hyg. 1996, 55, 536-546. [PubMed]

89. Vedanarayanan, V.; Sorey, W.H.; Subramony, S.H. Tick paralysis. Semin. Neurol. 2004, 24, 181-184. [CrossRef] [PubMed]

90. Mans, B.J.; Gothe, R.; Neitz, A.W.H. Biochemical perspectives on paralysis and other forms of toxicoses caused by ticks. Parasitology 2004, 129, 95-111. [CrossRef]

91. Ebel, G. Update on Powassan virus: Emergence of a North American tick-borne Flavivirus. Ann. Rev. Entomol. 2010, 55, 95-110. [CrossRef] [PubMed]

92. Edlow, J.; McGillicuddy, D. Tick paralysis. Infect. Dis. Clin. N. Am. 2000, 22, 397-413. [CrossRef] [PubMed]

93. Van Nunen, S. Tick-induced allergies: Mammalian meat allergy, tick anaphylaxis and their significance. Asia Pac. Allergy 2015, 5, 3-16. [CrossRef] [PubMed]

94. Platts-Mills, T.A.E.; Schuyler, A.J.; Commins, S.P. Anaphylaxis to the carbohydrate side chain Alpha-gal. Immunol. Allergy Clin. N. Am. 2015, 35, 247-260. [CrossRef] [PubMed]

95. Eremeeva, M.E.; Dasch, G.A. Challenges posed by tick-borne rickettsiae: Eco-epidemiology and public health implications. Front. Public Health 2015, 3, 55. [CrossRef] [PubMed]

96. Falco, R.C.; Fish, D.; Piesman, J. Duration of tick bites in a Lyme disease-endemic area. Am. J. Epidemiol. 1996, 143, 187-192. [CrossRef] [PubMed]

(C) 2017 by the authors. Licensee MDPI, Basel, Switzerland. This article is an open access article distributed under the terms and conditions of the Creative Commons Attribution (CC BY) license (http:/ / creativecommons.org/licenses/by/4.0/). 